\title{
Hormona luteinizante y actividad ovárica en respuesta a kisspeptina-10 y su asociación con IGF-1 y leptina en becerras pre-púberes
}

\section{Luteinizing hormone and ovarian activity in response to kisspeptin-10 and its association with IGF-1 and leptin in prepubertal heifers}

\author{
Rubén Santos Echevernáa,b, René Carlos Calderón Roblesc, Héctor Raymundo Vera Ávilad, Gerardo Perera-Marína, \\ J esús Alejandro Arreguín Arévaloe, Terry M. Nette, Carlos Gutiérrez Aguilara, Alejandro Villa-Godoya
}

\begin{abstract}
RESUMEN
Se evaluó el efecto de la kisspeptina-10 (Kiss-10), administrada repetidamente, sobre la liberación de LH y la actividad ovárica en becerras pre-púberes. Asimismo, se determinó la asociación de I GF-1 y leptina séricas con dichos efectos. Catorce (14) becerras Holstein o Suizo Pardo por Cebú (11.2 0.2 meses de edad; 187.4 $\pm 6.3 \mathrm{~kg}$ de peso), se asignaron aleatoriamente para recibir cada dos horas, durante tres días una aplicación i.v. de Kiss-10 (Kisspeptina10; $5 \mathrm{\mu g} / \mathrm{kg}$ de peso; $n=7$ ) o solución salina fisiológica (Testigo, $n=7$ ). Se colectó sangre cada 15 min de las 0-6, 24-30 y 72-78 h, y cada 2 h hasta las 84 h. Cada aplicación de Kiss-10 fue seguida de un incremento de LH, cuya magnitud (área bajo la curva) disminuyó $(P<0.05)$ con el tiempo. La Kiss-10 indujo una oleada preovulatoria de LH y formación de cuerpo lúteo en $\mathbf{2 8 . 5} \%$ de las becerras, mismas que presentaron las mayores $(P<0.05)$ concentraciones séricas de IGF-1 y las menores $(P<0.05)$ de leptina. Durante 63 días postratamiento no se detectaron cambios en las ondas foliculares atribuibles a Kiss-10 ( $P>0.05)$, y ninguna becerra manifestó actividad ovárica cíclica. Se concluye que la Kiss-10 administrada repetidamente a becerras pre-púberes es un estímulo suficiente para evocar incrementos consistentes de LH, para inducir la ovulación y actividad lútea en animales con concentraciones séricas elevadas de IGF-1 y bajas de leptina, pero no para inducir la ciclicidad estral.
\end{abstract}

PALABRAS CLAVE: Becerras pre-púberes, Kisspeptina, IGF-1, Leptina, Hormona luteinizante.

\begin{abstract}
We evaluated the effect of kisspeptin-10 (Kiss-10) administered repeatedly on the release of LH and ovarian activity in prepubertal heifers. We also assessed the association of serum IGF-1 and leptin with these effects. Fourteen Holstein or Brown Swiss by Zebu female calves (11.2 $\pm 0.2 \mathrm{mo}$ old, $187.4 \pm 6.3 \mathrm{~kg})$ were randomly assigned to receive every $2 \mathrm{~h}$ for three days an i.v. application of Kiss-10 (Kisspeptin-10; $5 \mu \mathrm{gg} / \mathrm{kg}$ of body weight, $\mathrm{n=} 7$ ) or saline solution (control, $n=7$ ). Blood was collected every 15 min for 0-6, 24-30 and 72-78 $h$, and every $2 h$ until 84 h. Each application of Kiss-10 was followed by an increase of LH whose magnitude (area under the curve) decreased (P<0.05) over time. Kiss-10 induced a preovulatory surge of LH and corpus luteum formation in $28.5 \%$ of the calves. Ovulating calves had the highest $(P<0.05)$ serum concentrations of IGF-1 and the lowest $(P<0.05)$ leptin. During 63 posttreatment days, no changes were detected in follicular waves attributable to treatments $(P>0.05)$ and heifers did not show cyclic ovarian activity. The conclusion is that Kiss-10 given repeatedly to prepubertal heifers is sufficient to evoke consistent increases of LH, to induce ovulation and luteal activity in animals with high IGF-1 and low leptin in peripheral blood but it is insufficient to establish regular estrous cyclicity.
\end{abstract}

KEY WORDS: Prepubertal heifers, Kisspeptin, IGF-1, Leptin, Luteinizing hormone.

Recibido el 24 de septiembre de 2013. Aceptado el 26 de noviembre de 2013.

a Facultad de Medicina Veterinaria y Zootecnia, Universidad Nacional Autónoma de México. Circuito Exterior S/N, Cubículo 2314 , Ciudad Universitaria, 04510 Coyoacán, México, DF. Tel. 5255562259 80. aavillagodoy@gmail.com. Correspondencia al último autor.

b Campo Experimental I guala, Instituto Nacional de Investigaciones Forestales, Agrícolas y Pecuarias (INIFAP), Iguala, Guerrero, México.

c Campo Experimental San Martinito, INIFAP. Tlahuapan, Puebla, México.

d CENID Fisiología y Mejoramiento Animal, INIFAP. Ajuchitlán, Querétaro, México.

e Departamento de Ciencias Biomédicas, Universidad Estatal de Colorado, Fort Collins, Colorado, USA.

Esta investigación fue parcialmente apoyada por: 1) Macroproyecto 7.03.02 de SDEI-UAIFE-UNAM. 2) DGAPA-PAPIIT- IN205510- UNAM. 3) Fondos fiscales INIFAP 2012: (Núm SINASO 18341619576). 


\section{INTRODUCCIÓN}

La pubertad representa una condición crítica en el desarrollo de los mamíferos y en la rentabilidad de las unidades de producción pecuaria(1). El inicio de este proceso reproductivo es precedido por un aumento en la frecuencia de pulsos de la hormona luteinizante (LH), en respuesta a un incremento en la secreción pulsátil de la hormona liberadora de gonadotropinas $(G n R H)(2)$. La LH actúa en los ovarios estimulando el desarrollo terminal de los folículos y el incremento en la síntesis y secreción de estrógenos, los cuales a su vez son responsables de inducir el estro y la ovulación(2). El cambio en el patrón de secreción pulsátil de la GnRH es el componente clave para iniciar la pubertad(3). Este cambio a su vez se deriva de la modificación funcional del "pulsador biológico", el generador hipotalámico de pulsos de $\mathrm{GnRH}$, cuya regulación neural y no neural es compleja y no ha sido dilucidada por completo(4).

La kisspeptina o metastina es una familia de péptidos hipotalámicos (Kiss-54, -14, -13 y -10; denominados de acuerdo al número de aminoácidos que los componen), altamente conservada en mamíferos(5), que está involucrada en la regulación de las neuronas de $\mathrm{GnRH}^{(6)}$. La administración de kisspeptina, ya sea en forma sistémica(7) o central $(8,9,10)$, induce la liberación de GnRH e indirectamente de las gonadotropinas hipofisiarias $(8,11)$, por lo que podría tener aplicaciones potenciales para manipular la reproducción.

En bovinos, la información disponible acerca de la participación de la kisspeptina en la activación puberal del eje reproductivo es limitada. En becerras pre-púberes, de las razas Holstein, Negra Japonesa y de las de cruzas de Holstein y Suizo por Cebú, la administración de un bolo i.v. de Kiss-10 ( $5 \mu \mathrm{g} / \mathrm{kg}$ de peso) indujo un incremento transitorio en la liberación de LH y de la hormona folículo estimulante (FSH)(12-15). La respuesta a Kiss-10 a esta dosis y vía de administración aumenta con la edad en becerras

\section{INTRODUCTION}

Puberty is a critical condition during the mammals development and the profitability of livestock production units(1). The beginning of this reproductive process is preceded by an increase in the frequency of luteinizing hormone (LH) pulses, in response to enhanced pulsatile secretion of gonadotropins releasing hormone $(\mathrm{GnRH})(2)$. LH acts in the ovaries by stimulating the final development of follicles as well as synthesis and secretion of estrogens, which in turn are responsible for inducing estrus and ovulation(2). The change in the pulsatile $\mathrm{GnRH}$ secretion pattern is the critical step that leads to onset of puberty(3). This change is induced by functional variations in the" biological switch", the hypothalamic generator of GnRH pulses, whose neural and non-neural regulation is complex and has not been completely understood(4).

Kisspeptin or metastin is the name given to a family of hypothalamic peptides that differ in the number of amino acid residues (Kiss-54, -14, -13 and -10$)$, and that are highly conserved in mammals(5). Kisspeptin participate in the regulation of the GnRH neurons functions(6). Kisspeptin administered, either systemically $(7)$ or centrally $(8,9,10)$, induces $\mathrm{GnRH}$ release and indirectly the rhythmicity of gonadotropins secretion $(8,11)$; therefore kisspeptin has a potential use for controlling reproduction in mammals.

In cattle, information relative to the role of kisspeptin on the peripuberal activation of the gonadal axis is limited. For instance, in prepuberal heifers of different breeds (Holstein, Black Japanese and crosses of Holstein or Brown Swiss by Zebu), a single i.v. administration of Kiss-10 $(5 \mu \mathrm{g} / \mathrm{kg}$ of body weight) induced a transient increase in peripheral $\mathrm{LH}$ and follicle stimulating hormone (FSH)(12-15); furthermore, the $\mathrm{LH}$ response to Kiss-10 given by the same route an in identical dose, increases with age in 4 to 11 mo-old calves(14). Thus available data suggest that heifers become more sensitive 
de 4 a 11 meses(14), lo cual permite sugerir que los animales adquieren una mayor sensibilidad a la kisspeptina a medida que se acercan a la pubertad. Asimismo, en becerras de 7 a 11 meses de edad, se demostró que la magnitud y duración de la respuesta de LH y FSH no aumenta al incrementar la dosis de Kiss-10 de 5 a $50 \mu \mathrm{g} / \mathrm{kg}$ de peso(15). En los estudios previos también se observó $(14,15)$ que la mayor respuesta de LH y FSH a Kiss-10 coincide con una elevada concentración circulante del factor de crecimiento parecido a la insulina (IGF-1) y una concentración de leptina decreciente. Por lo tanto, es posible que la leptina esté involucrada en acciones presensibilizadoras, mientras que el IGF-1 podría estar modulando los efectos de la Kiss-10 sobre el eje reproductivo de las becerras(14).

En experimentos realizados para tratar de adelantar la pubertad, al administrar GnRH en becerras, imitando la liberación pulsátil de la GnRH endógena, se logró inducir la formación de cuerpo lúteo en 28 y $33 \%$ de las becerras pero no la actividad cíclica ovulatoria $(16,17)$. Existen evidencias de que la Kiss-10 administrada en forma repetida induce la apertura vaginal en ratas pre-púberes $(9,10)$, así como la ovulación y formación de cuerpos lúteos en corderas próximas a la pubertad(18), en una elevada proporción de animales ( $>60 \%$ ). Por lo anterior, el objetivo del presente estudio fue determinar los efectos de la Kiss-10, administrada repetidamente, sobre la liberación de LH, la función lútea y el desarrollo folicular ovárico en becerras pre-púberes; asimismo se determinó la asociación de IGF-1 y leptina séricas con dichos efectos.

\section{MATERIALES Y MÉTODOS}

Todos los procedimientos empleados en este experimento fueron aprobados por el Subcomité Institucional para el Cuidado y Uso de Animales en Experimentación (SICUAE) del programa de Posgrado en Ciencias de la Producción y de la Salud Animal de la Facultad de Medicina Veterinaria y Zootecnia, UNAM. El estudio se to kisspeptin as they approach puberty. In addition, it is known that in 7 to 11 mo old heifer calves the magnitude and duration of $\mathrm{LH}$ and FSH response does not change by increasing the Kiss- 10 dose from 5 to $50 \mu \mathrm{g} / \mathrm{kg}^{(15)}$. It was also observed $(14,15)$ that the greatest response of $\mathrm{LH}$ to Kiss-10 coincides with a high circulating concentration of insulin-like growth factor-1 (IGF-1) and low leptin concentrations. Therefore, it is possible that leptin is involved in presensitization actions, while IGF-1 may be modulating positively the effects of Kiss-10 on the reproductive axis of heifer calves as it was proposed in a previous work(14).

In experiments designed to advance the onset of puberty, repeated administration of GnRH in heifers, induce formation of a corpus luteum in 28 and $33 \%$ of the treated heifers, however cyclic ovulatory activity did not occur in any of them $(16,17)$. In contrast to observations in cattle, there is evidence that Kiss-10 administered repeatedly induces the vaginal opening in prepubertal rats $(9,10)$, as well as ovulation and formation of corpora lutea in a high proportion (>60\%) of lambs that were approaching puberty(18). Consequently, the objective in the present study was to determine the effects of Kiss-10, administered repeatedly, on the release of $\mathrm{LH}$, luteal function and ovarian follicular development in prepubertal heifers; collaterally we determined the association between changes in serum IGF-1 and leptin with the variations on LH and ovarian responses to Kiss-10.

\section{MATERIALS AND METHODS}

All procedures used in this experiment were approved by the Institutional Sub-Committee for the Care and Use of Experimental Animals (SICUAE, acronym in Spanish) of the Faculty of "Medicina Veterinaria y Zootecnia", UNAM. The study was conducted at an experimental farm located at $19^{\circ} 51^{\prime} 03^{\prime \prime} \mathrm{N}$ and $97^{\circ} 12^{\prime} 48^{\prime \prime} \mathrm{W}$; the site is $500 \mathrm{~m}$ asl, the climate is subtropical humid, warm and is classified as Af (c), with annual average temperature of $20.8{ }^{\circ} \mathrm{C}(19)$. 
realizó en un sitio experimental dependiente del INIFAP, ubicado en Hueytamalco, Pue. El sitio se encuentra a 19o 51' 03" $\mathrm{N}$ y 970 12' 48" O, a 500 msnm. El clima es subtropical húmedo semicálido $\operatorname{Af}(\mathrm{c})$, con temperatura promedio anual de $20.8{ }^{\circ} \mathrm{C}(19)$.

\section{Tratamientos}

Se usaron 14 becerras pre-púberes de 11 a 13 meses de edad y $187.4 \pm 6.26 \mathrm{~kg}$ de peso (media \pm eem), resultantes de la cruza de animales Suizo Pardo o Holstein por Cebú. Las becerras se agruparon por genotipo, edad y peso, y de acuerdo a estos criterios, se asignaron aleatoriamente para recibir Kiss-10 (Kisspeptina-10; $5 \mu \mathrm{g} / \mathrm{kg}$ de peso, i.v., cada dos horas durante tres días; $\mathrm{n}=7$ ) o solución salina fisiológica (SSF; Testigo; $n=7$ ). En el presente estudio se aplicó Kiss-10 bovina(6) cuya secuencia peptídica es YNWNSFGLRY-NH2, con $>95 \%$ de pureza (Proimmune, Oxford, UK). Tanto SSF como Kiss-10 fueron administrados a través de un catéter insertado en una de las venas yugulares, el cual a su vez se utilizó para obtener muestras de sangre de acuerdo al esquema que se describe en la sección correspondiente. Antes de su aplicación, la Kiss10 fue diluida en SSF (1:125). El volumen total aplicado por becerra en el grupo Kiss-10 se usó como referencia para establecer el volumen de SSF que se aplicó en las becerras de dicho grupo.

\section{Manejo general}

Las becerras se alojaron por pares en corrales de $4 \times 6 \mathrm{~m}$, con piso de cemento, área techada $(4 \times 3 \mathrm{~m})$, comederos y bebederos. Para su adaptación al manejo y a la rutina de muestreo sanguíneo, las becerras se introdujeron a los corrales dos meses antes de la administración de tratamientos y durante este periodo se sometieron a sujeción con reata ( 2 h/día), cepillado de pelo y acostumbramiento a la presencia de personas. La alimentación consistió en forraje picado a libertad (heno de avena; $94.82 \%$ MS, 8.13 \% PC y 2.3 Mcal de EM/kg),

\section{Treatments}

Fourteen (14) prepubertal Brown Swiss or Holstein by Zebu heifers that were 11 to 13 mo old and weighed $187.4 \pm 6.26 \mathrm{~kg}$ (mean \pm SEM) were blocked by genotype, age and weight, then they were randomly assigned to the following treatments: Kiss-10 (Kisspeptin$10 ; 5 \mu \mathrm{g} / \mathrm{kg}$ of body weight; $\mathrm{n}=7$ ) or physiological saline solution (FSS; Control; $n=$ 7). Both treatments were given i.v., every two hours for three days. The peptide used(6) was a bovine Kiss-10 (YNWNSFGLRY-NH2) with > 95\% purity (Proimmune, Oxford, UK). FSS and Kiss-10 were administered through a catheter inserted into a jugular vein, which in turn was used to obtain blood samples according to the schedule described in the corresponding section. Before the application, Kiss-10 was diluted in FSS (1:125) and the total volume of FSS and Kiss-10/heifer was similar.

\section{General management}

Heifers were allotted by pairs in $4 \times 6 \mathrm{~m}^{2}$ pens with cement floor, a shaded area $(4 \times 3 \mathrm{~m})$, and equipped with individual feeders and drinkers. For adaptation purposes, heifers were housed in experimental pens 2 mo before, during and after the administration of treatments. During the adaptation period, they were restraint, brushed and handled $(2 \mathrm{~h} / \mathrm{d})$. Diet consisted of ad libitum chopped forage (oat hay; $94.82 \%$ MS, $8.13 \%$ PC and 2.3 Mcal $\mathrm{EM} / \mathrm{kg}), 4 \mathrm{~kg} / \mathrm{d}$ of concentrate $(94.49 \% \mathrm{MS}$, $17.97 \% \mathrm{CP}$ and $2.5 \mathrm{EM} / \mathrm{kg}$ Mcal), mineral salts and water ad libitum. The experiment ended $63 \mathrm{~d}$ after treatments administration was completed.

\section{Body measurements}

Body weight was recorded every $14 \mathrm{~d}$ from the arrival of animals to pens and until the end of the experiment. A day before first treatments application, height, body condition (BC), thickness of the backfat and depth of the Longissimus dorsi muscle were determined. Height was the vertical distance between the 
$4 \mathrm{~kg}$ de alimento concentrado al día $(94.49 \%$ MS, $17.97 \%$ PC y $2.5 \mathrm{Mcal}$ de EM/kg), sales minerales y agua a libertad. El periodo experimental concluyó 63 días después de finalizados los tratamientos.

\section{Determinación de medidas corporales}

El peso vivo de los animales se registró cada 14 días desde su llegada a los corrales de experimentación y hasta el final del estudio; a partir de estos registros se determinó la ganancia diaria promedio de peso (GDP) previa al inicio del periodo experimental. Un día antes de la aplicación de tratamientos, a cada becerra se le determinó la altura a la cruz, condición corporal (CC), grosor de la grasa dorsal y profundidad del músculo Longissimus dorsi. La altura a la cruz fue la distancia vertical entre el piso y la unión escapular. La CC fue calificada de manera independiente por tres personas(20) (escala de 1 a 5 puntos, $1=$ emaciado y $5=$ obeso) y el promedio de estas calificaciones se usó como variable de respuesta. El grosor de la grasa dorsal y la profundidad del músculo Longissimus dorsi (medidos entre la 12va y la 13va costilla) se determinaron mediante ultrasonografía(21), utilizando para ello un aparato Kaixin 5000 y transductor lineal de $3.5 \mathrm{MHz}$ (Xuzhou Kaixin Electronic Instruments Co., Xuzhou, Jiangsu, China).

\section{Muestreo sanguíneo}

Cada tercer día desde dos semanas antes de iniciar el estudio y hasta finalizarlo, se obtuvieron muestras de sangre por punción de la vena coxígea y colección en tubos "vacutainer". Las muestras se procesaron para obtención de suero (refrigeración por $3 \mathrm{~h}$ y posterior centrifugación a 1,500 xg por $15 \mathrm{~min})$. El suero se congeló a $-20^{\circ} \mathrm{C}$ hasta determinar por radioinmunoanálisis (RIA) la concentración de progesterona (P4). La concentración de P4 se utilizó como indicador de actividad lútea (P4; valores $\pm 1 \mathrm{ng} / \mathrm{ml}$ ) y confirmación del estado pre-puberal (P4; valores $<1 \mathrm{ng} / \mathrm{ml}$ ) de las becerras.

Adicionalmente y una hora antes de iniciar los tratamientos correspondientes, a cada becerra floor and the scapular union (withers). $\mathrm{BC}$ was scored independently by three people(20) and averaged (scale of 1 to 5 points, $1=$ emaciated and $5=$ obese). Backfat thickness and depth of $\mathrm{L}$. dorsi muscle (between the 12th and the 13th rib) were determined by ultrasound(21), using a Kaixin 5000 equipment and a linear transducer of 3.5 MHz (Xuzhou Kaixin Electronic Instruments Co., Xuzhou, J iangsu, China).

Blood sampling

Every other day from 2 wk before through the end of the experiment, blood samples were obtained from heifers by puncture of the coccyxgeal vein, serum was obtained and frozen at $-20^{\circ} \mathrm{C}$ until progesterone concentration (P4) was quantified. P4 was used as indicator of luteal activity $( \pm 1 \mathrm{ng} / \mathrm{ml})$ and for confirmation of prepubertal condition $(<1 \mathrm{ng} / \mathrm{ml})$ of heifers. In addition, one hour before the beginning of treatments a sterile, plastic catheter was inserted in one of the jugular veins (probe Kortex caliber $5 \mathrm{FR}$ and $90 \mathrm{~cm}$ length; Catalogue K-733; Trokar S.A de C.V., Mexico). For this purpose, the perijugular area $(5 \times 5 \mathrm{~cm})$ was previously shaved and anesthetized ( $2 \%$ lidocaine, $2 \mathrm{mg} / \mathrm{cm}^{2}$ ). Through the catheter, blood was collected every $15 \mathrm{~min}$ in the following intervals: 0 to $6 \mathrm{~h}, 24$ to 30 , and 72 to $78 \mathrm{~h}$ relative to initiation of treatments, as well as every $2 \mathrm{~h}$ between intensive sampling intervals and during $84 \mathrm{~h}$ after the end of treatments application. The first samples were obtained immediately before each Kiss-10 or FSS administration. Serum samples were obtained and stored as described previously. LH concentrations were determined in all serum samples taken through catheters.

Ultrasonography of ovaries and detection of signs of estrus

Ultrasound images of the ovaries were obtained at the beginning and end of treatments application, and then every other day until the d 63 (intra-rectal transducer of $7.5 \mathrm{MHz}$ for a 500 Kaixin ultrasound). From ultrasound images the presence of corpora lutea $(\mathrm{CL})$ was identified, and the diameter of the two largest 
se le insertó un catéter estéril de plástico en una de las venas yugulares (Sonda Kortex calibre 5 FR y longitud 90 cm; Catálogo K-733; Trokar S.A de C.V). Para ello, la zona peri-yugular $(5 \times 5 \mathrm{~cm})$ fue previamente rasurada $\mathrm{y}$ anestesiada (lidocaína al $2 \%, 2 \mathrm{mg} / \mathrm{cm}^{2}$ ). A través del catéter, se colectó sangre cada 15 min en los periodos: 0 a $6 \mathrm{~h}, 24$ a $30 \mathrm{~h}$, y 72 a $78 \mathrm{~h}$ de iniciados los tratamientos, así como cada 2 h entre muestreos intensivos, y al terminar estos hasta las $84 \mathrm{~h}$. Las primeras muestras se obtuvieron inmediatamente antes de cada administración de Kiss-10 o SSF. El suero de estas muestras se obtuvo y almacenó como se indicó anteriormente.

Ultrasonografía de ovarios y detección de signos de estro

En cada becerra se obtuvieron imágenes ultrasonográficas de los ovarios el día previo al inicio de los tratamientos y, después de terminados estos cada tercer día hasta el día 63 (transductor intra-rectal de $7.5 \mathrm{MHz}$ para equipo Kaixin 500). A partir de estos registros se identificó la presencia de cuerpo lúteo (CL) y se obtuvo el diámetro de los dos folículos de mayor tamaño, así como el número de folículos mayores a $5 \mathrm{~mm}^{(22)}$.

Desde dos meses antes de iniciar el estudio y hasta su final, se llevó a cabo una supervisión para identificar a las becerras que presentaran conducta de estro (dos periodos de observación/ día en un corral comunal; 0700 a 0800 y 1900 a 2000 h).

\section{Medición de hormonas}

La LH se determinó mediante RIA en todas las muestras obtenidas entre las 0 y $84 \mathrm{~h}$ con relación a la aplicación de tratamientos. EI RIA para LH fue en fase líquida de $120 \mathrm{~h}$ de incubación a 4ㅇ $\mathrm{C}$, siguiendo el procedimiento descrito por Arrieta et al(23). La hormona USDAbLH (AFP11743B) se utilizó como trazador incorporando $\mathrm{Na}^{125}$ I mediante el método del lodo-gen y como curva patrón a dosis desde 0.01 hasta $10 \mathrm{ng}$ por tubo. El primer anticuerpo follicles as well as the number of follicles $>5$ $\mathrm{mm}$ were recorded(22).

From two months before through the end of the study, heifers were moved twice a day to a farmyard to be observed for detection of signs of estrus ( 0700 to $0800 \mathrm{~h}$ and 1900 to $2000 \mathrm{~h})$.

Hormonal measurements

LH was determined by a liquid phase radioimmuneassay (RIA) in all samples obtained between 0 and $84 \mathrm{~h}$ relative to treatments application, following the procedure described by Arrieta et al(23). USDA-bLH (AFP11743B) was used as a tracer, incorporating $\mathrm{Na} 125$ | by the iodo-gen method. The standard curve was constructed from 0.01 through 10 ng per tube. The first antibody was obtained from rabbit to NIDDK-oLH-26 (anti-oLH-26), validated in cattle by Perera-Marin et al(24) and taken to a final dilution of 1:400,000. Separation of bound and free fractions was by the addition of a second antibody against rabbit IgG produced in donkey ( $1: 80$ dilution). In three assays, the sensitivity was $0.03 \mathrm{ng} / \mathrm{ml}$ and the intra- and inter-assay C.V. were 6.73 and $6.57 \%$, respectively. IGF-1 and leptin were quantified in samples obtained at $0,24,48$ and $72 \mathrm{~h}$ from the beginning of treatments. IGF-1 was measured by an immunoabsorbent assay (IGF-1 ELISA $®$, ALPCO Diagnostics, Salem, $\mathrm{NH}, \mathrm{USA}$ ); the sensitivity of the assay was $5.86 \mathrm{ng} / \mathrm{ml}$ and the intra-assay CV was $0.57 \%$. Leptin was analyzed by a multi-species liquid phase RIA kit (XL - $85 \mathrm{~K}$, Linco Research Inc., St. Charles, MO, USA)(25). The sensitivity of the assay was $1.0 \mathrm{ng} / \mathrm{ml}$ and the within assay CV was $3.8 \%$. Progesterone was determined by RIA by a solid phase RIA kit (PROG - CTRIA ${ }^{\circledR}$, Cisbio Bioassay, Sorgues, France) with a sensitivity of $0.15 \mathrm{ng} / \mathrm{ml}$, and an intra-assay CV of $8.8 \%$.

\section{Response variables}

From each increment of Kiss-10 induced LH in serum, the area under the curve (AUC) was calculated; similarly, during the same periods, 
generado en conejo correspondió a la hormona NIDDK-oLH-26 (anti-oLH-26) validado en bovinos por Perera-Marín et al(24) a una dilución final de 1:400,000. La separación de la fracción unida de la fracción libre se realizó con un segundo anticuerpo contra IgG de conejo generado en burro (dilución 1:80). En tres ensayos la cantidad mínima detectable fue 0.03 $\mathrm{ng} / \mathrm{ml}$ y los coeficientes de variación (CV) intrae inter-ensayo fueron 6.73 y $6.57 \%$, respectivamente. El IGF-1 y la leptina se determinaron en muestras obtenidas a las 0 , 24,48 y $72 \mathrm{~h}$ de iniciados los tratamientos. El IGF-1 se cuantificó mediante un ensayo inmunoabsorbente (IGF-1 ELISA ${ }^{\circledR}$, ALPCO Diagnostics, Salem, $\mathrm{NH}$ ); la sensibilidad del ensayo fue de $5.86 \mathrm{ng} / \mathrm{ml}$ y el CV intra-ensayo fue $0.57 \%$. La leptina se analizó mediante RIA con un estuche comercial multiespecies de fase líquida (XL-85K, Linco Research Inc, St. Charles, MO)(25), con una sensibilidad de $1.0 \mathrm{ng} / \mathrm{ml}$ y un CV intra-ensayo de $3.8 \%$. La progesterona se cuantificó mediante RIA con un estuche comercial de fase sólida (PROG-CTRIA®, Cisbio Bioassay, Sorgues, France) cuya sensibilidad fue de $0.15 \mathrm{ng} / \mathrm{ml}$, con un CV intra-ensayo de $8.8 \%$.

Variables de respuesta

Se determinó el área bajo la curva (AUC) de cada incremento en las concentraciones séricas de LH provocado por la administración de Kiss$10 \mathrm{y}$, en paralelo, durante periodos similares del pulso endógeno de LH de mayor tamaño en becerras del grupo testigo. Se consideraron como incrementos de LH inducidos por la administración de Kiss-10 o pulsos endógenos en el grupo testigo, cuando al menos en dos muestras consecutivas la concentración de LH fue mayor al promedio más dos desviaciones estándar de las concentraciones de la hormona a las 0,2 y $4 \mathrm{~h}$ de iniciados los tratamientos. El AUC se calculó como la suma de las concentraciones de LH consideradas como incrementos asociados a la administración de Kiss-10, o a un pulso endógeno en el grupo testigo. Para ambos grupos se determinó la frecuencia de incrementos de LH sérica, durante in the endogenous highest $\mathrm{LH}$ pulse in control calves, AUC was determined. Both, spontaneous pulse or Kiss-10 induced increments of $\mathrm{LH}$ occurred when at least in two consecutive samples LH concentration was higher than the mean values plus 2 SD of the hormone concentrations at 0,2 and $4 \mathrm{~h}$ from the first treatments application. AUC was calculated as the sum of LH concentrations within a Kiss-10 induced increment or an endogenous pulse. Frequency of endogenous pulses or Kiss-10 induced increments of $\mathrm{LH} / 6 \mathrm{~h}$ of each interval of intensive sampling was determined. $\mathrm{LH}$ concentrations determined in samples collected every two hours (0 to $84 \mathrm{~h}$ ), were used to identify a preovulatory surge (increase of LH above the mean from all samples $+2 \mathrm{SD}$ in two or more consecutive samples, followed by at least two samples at baseline level). The occurrence of ovulation was when a preovulatory LH surge was identified prior a CL detected by ultrasonography and a concomitant increase of serum P4 ( $\geq 1 \mathrm{ng} / \mathrm{ml}$ ) was observed. Records of ultrasound images of the ovaries were used to characterize the waves of follicular development during the experimental period(26), as well as their number and duration.

Statistical analyses

Comparison between experimental groups for data relative to body measurements (body weight, pretreatment ADG, height, $B C$, backfat thickness, depth of L. dorsi muscle), total follicles $\geq 5 \mathrm{~mm}$ in diameter, diameter of the two largest follicles as well as mean serum levels of leptin and IGF-1, were performed by a " $t$ " Student test. For data relative to response variables that were recorded repeatedly during the experiment, the analyses were by ANOVA for a repeated measurements design (serum concentrations of LH, leptin and IGF-1, AUC of $\mathrm{LH}$ increments, duration of dominant follicles and follicular waves). In addition, binomial responses were compared by Chi-square (occurrence of preovulatory LH surge and CL). To determine the association between body measurements and ovarian or endocrine 
cada uno de los periodos de muestreo intensivo de $6 \mathrm{~h}$ (frecuencia=número de incrementos durante el periodo). A partir de las concentraciones de $\mathrm{LH}$ determinadas en las muestras colectadas cada dos horas ( 0 a $84 \mathrm{~h}$ ), se identificó a las becerras que presentaron una oleada preovulatoria de LH (incremento de LH mayor a la media $+2 \mathrm{DE}$ en dos o más muestras consecutivas). La presentación de ovulaciones se determinó mediante la identificación ultrasonográfica de $\mathrm{CL}$, coincidente con un incremento de P4 $( \pm 1 \mathrm{ng} / \mathrm{ml})$. Con base en los registros ultrasonográficos de los ovarios se caracterizaron las ondas de desarrollo folicular durante el periodo experimental(26), estimando su número y duración.

Análisis estadístico

La comparación entre grupos experimentales de los valores al inicio del estudio para peso vivo, ganancia diaria promedio (GDP) de peso pre-tratamientos, altura a la cruz, CC, grosor de grasa dorsal, profundidad del músculo $L$. variables, an analysis of multiple linear correlations was performed. The statistical package SAS was used in all cases(27) through the procedures for general linear models (PROC GLM) or frequency (PROC-FREQ) analysis and when necessary, separation of means was performed by the least square (LSMEANS) procedure.

\section{RESULTS}

Three weeks after application of treatments, one calf of the Kiss-10 group was withdrew from the study due to an infectious disease, so data from this animal related to the response variables associated with follicular waves were not recorded but data relative to hormones in response to Kiss-10 were taken, analyzed and included in results. At the beginning of the study, heifers in the two experimental groups were homogeneous in body measurements, ovarian condition as well as serum leptin and IGF-1 (Table 1; P>0.05). The ADG during the 2 mo previous to the treatments administration

Cuadro 1. Media \pm EEM de la edad, medidas corporales y ganancia diaria de peso pre-tratamientos; así como desarrollo folicular ovárico y concentraciones de leptina e IGF-1 al inicio del experimento en becerras pre-púberes tratadas con Kiss-10

Table 1. Mean \pm SEM of pre-treatment age, body measurements and daily weight gain; as well as follicular development and leptin and IGF-1 concentrations at the beginning of the experiment in prepubertal heifers treated with Kiss-10

\begin{tabular}{lccr}
\hline & \multicolumn{3}{c}{ Groups } \\
\cline { 2 - 4 } Variable & Control & Kisspeptin-10 & $P=$ \\
\hline Age, month & $11.4 \pm 0.21$ & $10.9 \pm 0.32$ & 0.2348 \\
Body weight, $\mathrm{kg}$ & $188.6 \pm 9.3$ & $186.1 \pm 9.1$ & 0.8510 \\
Wither height, cm & $111.0 \pm 2.32$ & $109.4 \pm 2.64$ & 0.6051 \\
Body condition score, point & $2.93 \pm 0.09$ & $2.92 \pm 0.10$ & 0.9923 \\
Backfat thickness, mm & $2.50 \pm 0.13$ & $2.32 \pm 0.10$ & 0.3294 \\
L. dorsi muscle depth, mm & $26.87 \pm 1.40$ & $25.40 \pm 0.85$ & 0.3888 \\
Daily weight gain, kg & $0.71 \pm 0.08$ & $0.87 \pm 0.16$ & 0.3837 \\
Follicles larger than 5 mm, number & $13.29 \pm 1.3$ & $10.71 \pm 1.16$ & 0.1798 \\
Diameter of the largest follicle, mm & $7.71 \pm 0.76$ & $8.85 \pm 0.52$ & 0.2393 \\
Diameter of the second largest follicle, mm & $5.42 \pm 0.42$ & $6.42 \pm 0.49$ & 0.1518 \\
Serum leptin, $\mathrm{ng} / \mathrm{ml}$ & $3.23 \pm 0.44$ & $3.32 \pm 0.81$ & 0.9206 \\
Serum IGF-1, ng/ml & $159.4 \pm 13.43$ & $175.7 \pm 34.32$ & 0.6677 \\
\hline
\end{tabular}


dorsi, total de folículos $\geq 5 \mathrm{~mm}$, diámetro del folículo mayor y del segundo en tamaño, concentraciones séricas de leptina e IGF-1, se realizó mediante la prueba " $\mathrm{t}$ " de Student. En el caso de variables de respuesta que se registraron en varias ocasiones durante el periodo experimental, la comparación fue mediante ANDEVA para un diseño de mediciones repetidas (concentraciones séricas de LH, leptina e IGF-1, AUC de incrementos de $\mathrm{LH}$, duración de ondas foliculares y diámetros máximos de los folículos dominantes). A su vez, las respuestas binomiales se compararon por Ji cuadrada (presentación de oleada preovulatoria de LH y presentación de $\mathrm{CL}$ ). Por otra parte, con el fin de determinar el grado de asociación entre variables corporales y de actividad ovárica y endocrina al inicio el periodo experimental, se realizó un análisis de correlación lineal múltiple. En todos los casos se utilizó el paquete estadístico SAS(27) con sus procedimientos para modelos lineales generales (PROC-GLM) o para análisis de frecuencias (PROC-FREQ) y, en su caso, la separación de medias por el procedimiento de medias de cuadrados mínimos (LSMEANS). was also similar between groups, with an overall mean of $0.79 \pm 0.12 \mathrm{~kg} / \mathrm{d}$.

Repeated administration of Kiss-10 resulted in successive increments of LH (Figure 1-A). With each Kiss-10 application, AUC of the LH increments gradually decreased in each of the three first successive applications of Kiss-10 and then remained low and stable (Figure 1-B). Relative to endogenous $\mathrm{LH}$ pulses in control animals, AUC of the LH increments induced by Kiss-10 was 7.07, 4.95 and 3.20 times higher in the first three applications of the neuropeptide, respectively $(\mathrm{P}<0.01$; Figure $1-\mathrm{B})$. From $26 \mathrm{~h}$ after the beginning of treatments to the end of the study, AUC corresponding to Kiss-10 induced increments and endogenous pulses of $\mathrm{LH}$ did not differ between them ( $P>0.05$; Figure 1-B).

The AUC mean for LH during the 0 to $6 \mathrm{~h}$ interval (Table 2), was approximately nine times higher for the Kiss-10 animals than for pulses in the control group $(P<0.05)$. In contrast, $\mathrm{LH}$ AUC did not differ between experimental groups during the 24 to $30 \mathrm{~h}$ and 72 to $78 \mathrm{~h}$ intervals

Figura 1. Respuesta de hormona luteinizante (LH) a Kisspeptin-10 o pulsos espontáneos de LH en animales testigo. A: Perfil de LH (media \pm EEM) después de iniciados los tratamientos (flecha). B: Área bajo la curva (AUC) de los incrementos de $\mathrm{LH}$ registrados en intervalos de dos horas relativos a cada aplicación de los tratamientos. * $(P<0.01)$

Figure 1. Response of luteinizing hormone (LH) to Kisspeptin-10 or LH spontaneous pulses recorded in Controls. A: Profile of LH (Mean \pm SEM) after the beginning of treatments (arrow). B: Area under the curve (AUC) of LH increments during the $2 \mathrm{~h}$ intervals following each treatment application. * $(P<0.01)$
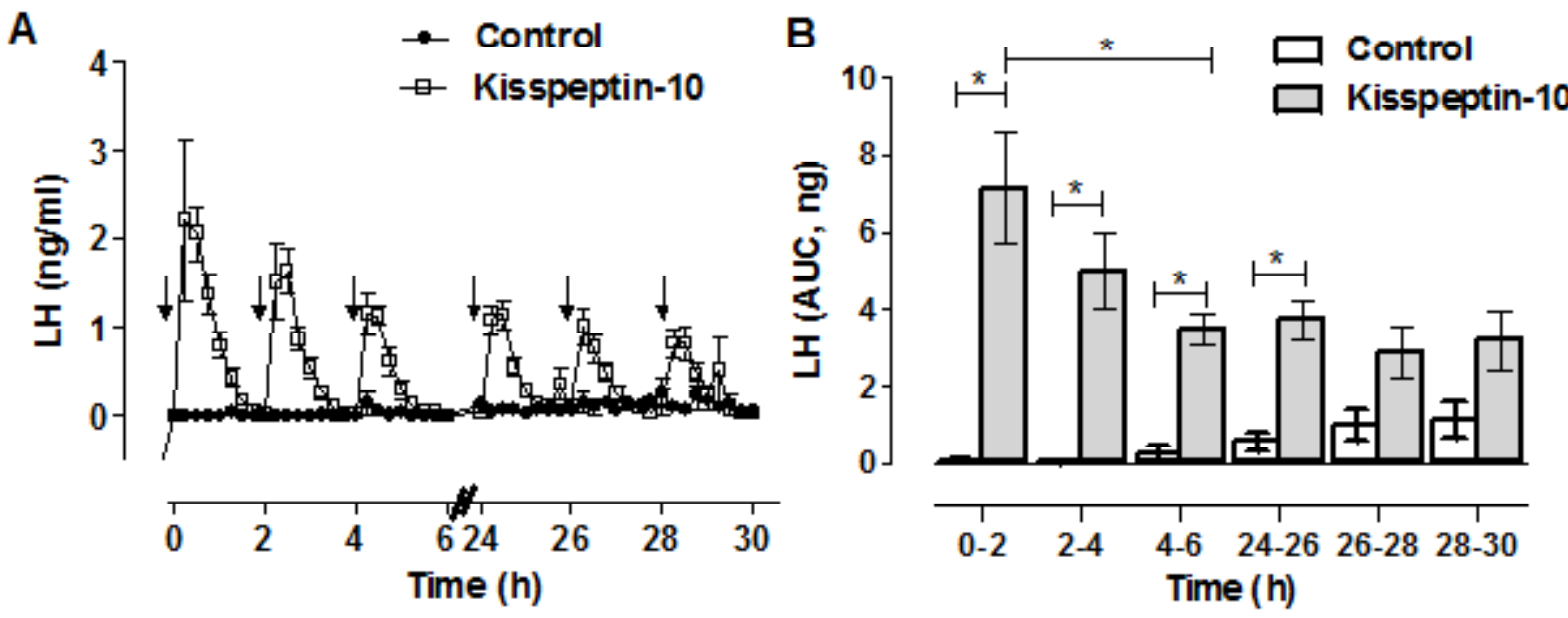
Cuadro 2. Media \pm EEM del número y área bajo la curva (AUC) de la respuesta de LH a Kiss-10 o de pulsos espontáneos de LH (solución salina) en diferentes periodos de muestreo sanguíneo de becerras prepúberes

Table 2. Mean \pm SEM of the number and area under the curve (AUC) of the LH response to Kiss-10 or LH spontaneous pulses (saline solution) during different blood sampling intervals in pre-pubertal heifers

\begin{tabular}{llll}
\hline Sampling period $(\mathrm{h})$ & Treatments $(\mathrm{n}=7$ each group) & Pulse frequency (pulses/6 h) & AUC $(\mathrm{ng})$ \\
\hline \multirow{2}{*}{0 to 6} & Control & $0.28 \pm 0.18$ & $0.78 \pm 0.61 \mathrm{a}$ \\
& Kisspeptin-10 & - & $7.12 \pm 1.45 \mathrm{C}$ \\
& & $1.00 \pm 0.21$ & $1.76 \pm 0.43 \mathrm{~b}$ \\
24 to 30 & Control & - & $3.37 \pm 0.52 \mathrm{~b}$ \\
& Kisspeptin-10 & & \\
72 to 78 & Control & $0.85 \pm 0.34$ & $1.47 \pm 0.55 \mathrm{ab}$ \\
& Kisspeptin-10* & $0.40 \pm 0.24$ & $0.62 \pm 0.15 \mathrm{a}$ \\
\hline
\end{tabular}

abc Different letters within variable indicate difference between treatment means $(P<0.05)$.

* Two heifers that had an LH preovulatory surge were not included for the analysis of data.

\section{RESULTADOS}

Tres semanas después del inicio de la aplicación de los tratamientos, una becerra del grupo Kisspeptina-10 se retiró del estudio por haber padecido una enfermedad infecciosa, por lo que no existieron datos de este animal relacionados con las variables de respuesta asociadas a las ondas de desarrollo folicular pos-tratamiento; en los análisis de respuesta hormonal a Kiss-10 sí fue contabilizada.

Al inicio del estudio, las becerras en los dos grupos experimentales fueron homogéneas en cuanto a medidas corporales, estado ovárico y concentración sérica de leptina e IGF-1 (Cuadro 1; P>0.05). La GDP registrada en los dos meses previos a la administración de los tratamientos también fue similar entre grupos, con una media general de $0.79 \pm 0.12 \mathrm{~kg} /$ día

La administración repetida de Kiss-10 provocó incrementos sucesivos de LH (Figura 1-A). Con cada aplicación de Kiss-10, el AUC del incremento de LH disminuyó gradualmente en las primeras tres aplicaciones y después se mantuvo relativamente estable (Figura 1-B). Comparado con el AUC de los pulsos endógenos en el grupo testigo, el AUC del incremento de
$(P>0.05)$. Through these three first periods AUC mean had a progressive decrease in the Kisspeptin-10 group $(P<0.05)$. In contrast, AUC mean increased in the control group during the 24 to $30 \mathrm{~h}$ interval when compared with 0 to $6 \mathrm{~h}$; subsequently. Once treatments were removed (end of 72 to $78 \mathrm{~h}$ interval), number and amplitude of $\mathrm{LH}$ pulses were similar $(P>0.05)$ between experimental groups.

A Kiss-10 induced preovulatory surge of $\mathrm{LH}$ followed by a $\mathrm{CL}$ occurred in $28.5 \%$ of the treated heifers (vs $0 \%$ in control animals). The preovulatory surges began at $48 \pm 5.65 \mathrm{~h}$ after the first application of Kiss-10 and the mean duration of them was $8.0 \pm 2.82 \mathrm{~h}$. P4 serum levels during luteal activity of the responding heifers began $6 \mathrm{~d}$ after the first application of Kiss-10, and the CLs remained functional during 4 and 12 d. Subsequently progesterone concentrations returned to values $<1 \mathrm{ng} / \mathrm{ml}$ that were sustained until the end of the study, thus after ovulation heifers returned to a prepubertal-like condition. None of the calves in both groups displayed signs of estrous behavior or cydic estrous activity during the experimental period. At $63 \mathrm{~d}$ post-treatment, number and duration of follicular waves, and the maximum 
LH en respuesta a Kiss-10 fue 7.07, 4.95 y 3.20 veces mayor en las tres primeras aplicaciones del neuropéptido ( $\mathrm{P}<0.01$; Figura 1-B). A partir de las $26 \mathrm{~h}$ de iniciados los tratamientos, el AUC del incremento de LH provocado por la Kiss-10 fue similar en magnitud comparado con el AUC de los pulsos endógenos de $\mathrm{LH}$ en el grupo testigo ( $P>0.05$; Figura 1-B).

El promedio del AUC durante el periodo de 0 a $6 \mathrm{~h}$ de iniciados los tratamientos (Cuadro 2) fue mayor para el grupo en que se administró Kiss-10 ( $P<0.05$; AUC 9 veces mayor en Kisspeptina-10 vs testigo), pero no difirió entre grupos experimentales en los periodos de 24 a $30 \mathrm{~h}$ y de 72 a $78 \mathrm{~h}$. A través de estos tres periodos el valor promedio de AUC presentó una disminución progresiva en el grupo Kisspeptina-10 $(\mathrm{P}<0.05)$. En contraste, esta variable presentó un incremento en el grupo testigo durante el periodo de 24 a $30 \mathrm{~h}$ con respecto al de 0 a $6 \mathrm{~h}$; posteriormente el AUC de LH se mantuvo. Una vez retirados los tratamientos (periodo 72 a $78 \mathrm{~h}$ ), el número y la amplitud de los pulsos de LH fue similar $(P>0.05)$ entre grupos experimentales. diameter of the dominant follicles were similar between experimental groups ( $P>0.05$; Figure 2 ); during that interval, duration of follicular waves and the diameter of dominant follicles increased from the 6th and 5th wave and thereafter, relative to previous waves in control and Kisspeptin-10 groups, respectively $(P<0.05)$.

Repeated application of Kiss-10 did not affect $(P>0.05)$ serum concentrations of IGF-1 and leptin but heifers that ovulated in response to Kiss-10 had the highest serum concentrations of IGF-1 ( $\mathrm{P}<0.05$; Figure 3-A). In contrast, serum concentration of leptin (Figure 3-B), which did not vary during the sampling period, were the lowest in heifers that ovulated $(P<0.05)$.

Serum concentrations of IGF-1 at the beginning of the experimental period were positively correlated $(P<0.05)$ with body weight $(r=0.70)$, body condition $(r=0.58)$ and height of heifers $(r=0.78)$. However, circulating leptin concentrations were significantly correlated only with age of heifers $(r=0.62 ; P<0.05)$. Values at the beginning of the experimental period of thickness of back fat, L. dorsi muscle depth and variables

Figura 2. Media \pm EEM de la duración (A) y diámetro máximo (DMax) del folículo dominante (B) de las ondas de desarrollo folicular registradas durante 63 días posteriores a la última aplicación de los tratamientos de Kisspeptina-10 0 solución salina fisiológica en becerras pre-púberes. ${ }^{*} P<0.05$

Figure 2. Mean \pm SEM of duration (A) and maximum diameter (DMax) of dominant follicles (B) during follicular waves recorded during $63 \mathrm{~d}$ after the last application of Kisspeptin-10 or saline solution in prepubertal heifers. ${ }^{*} P<0.05$

A

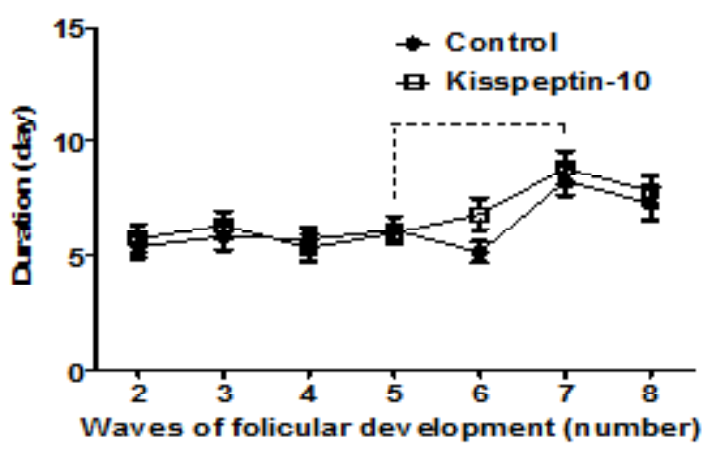

B

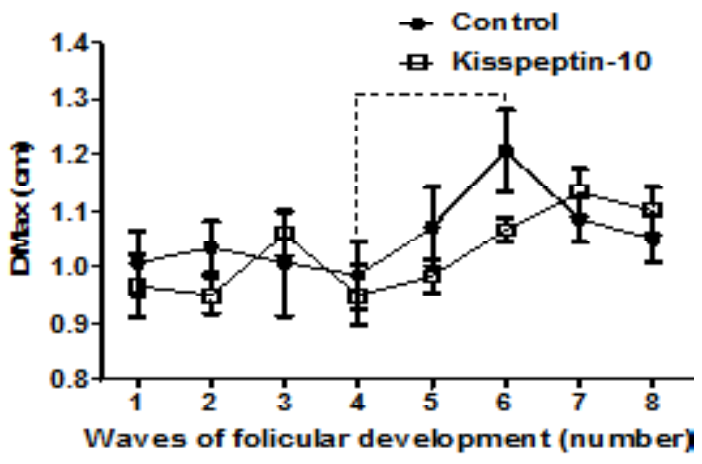

There were no effects of treatment or treatment by follicular wave interaction $(P>0.05)$. 
La Kiss-10 indujo una oleada preovulatoria de LH seguida de formación de un CL en $28.5 \%$ de las becerras tratadas, mientras que en el grupo testigo ninguna becerra la presentó. La oleada preovulatoria inició $48 \pm 5.65$ h después de la primera aplicación de Kiss-10 y tuvo una duración de $8.0 \pm 2.82 \mathrm{~h}$. De acuerdo a los niveles séricos de $\mathrm{P} 4$, la actividad lútea (concentración $\pm 1 \mathrm{ng} / \mathrm{ml}$ ) en dichas becerras inició seis días después de la primera aplicación de Kiss-10 y los dos CL permanecieron funcionales durante 4 y 12 días; posteriormente las concentraciones de progesterona volvieron a ser inferiores a $1 \mathrm{ng} / \mathrm{ml}$, lo cual se mantuvo hasta el final del estudio; es decir que después de ovular, las becerras volvieron a un estado similar al prepuberal.

Ninguna de las becerras en ambos grupos experimentales presentó signos conductuales de estro o actividad cíclica estral durante el periodo experimental. En los 63 días pos-tratamiento, el número y duración de las ondas de desarrollo related to the ovarian follicles, were not correlated with serum concentrations of IGF-1 and leptin ( $P>0.05)$; similarly, changes in serum concentrations of IGF-1 and leptin were not correlated with each other $(P>0.05)$.

\section{DISCUSSION}

Successive applications of Kiss-10 given intravenously induced $\mathrm{LH}$ release in prepubertal heifers, nevertheless, LH increments decreased in amplitude over time. In agreement with our hypothesis, Kiss-10 applied repeatedly induced ovulation but only in those heifers that had high circulating concentrations of IGF-1 and low concentrations of leptin. Kiss-10 did not induce the establishment of ovulatory cyclical activity or estrus and did not affect ovarian follicular development after treatment; consequently it may be considered that exogenous Kiss-10 exerts a temporary and partial effect on the mechanisms that lead toward puberty.

Figura 3. Concentración sérica de IGF-1 (A) y leptina (B) de becerras pre-púberes tratadas cada dos horas por tres días con Kiss-10 (círculos negros) o solución salina fisiológica (círculos blancos) en muestras de sangre tomadas a 0, 24, 48 y $72 \mathrm{~h}$ de los tratamientos

Figure 3. Serum concentration of IGF-1 (A) and leptin (B) of pre-pubertal heifers treated every two hours for three days with Kiss-10 (black circles) or saline solution (white circles). Blood samples were taken at 0, 24, 48 and $72 \mathrm{~h}$ relative to treatments

A

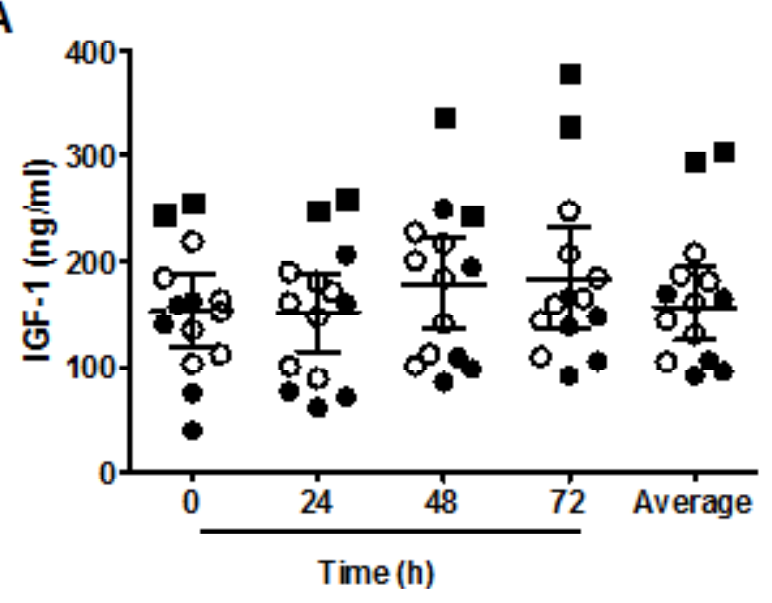

B

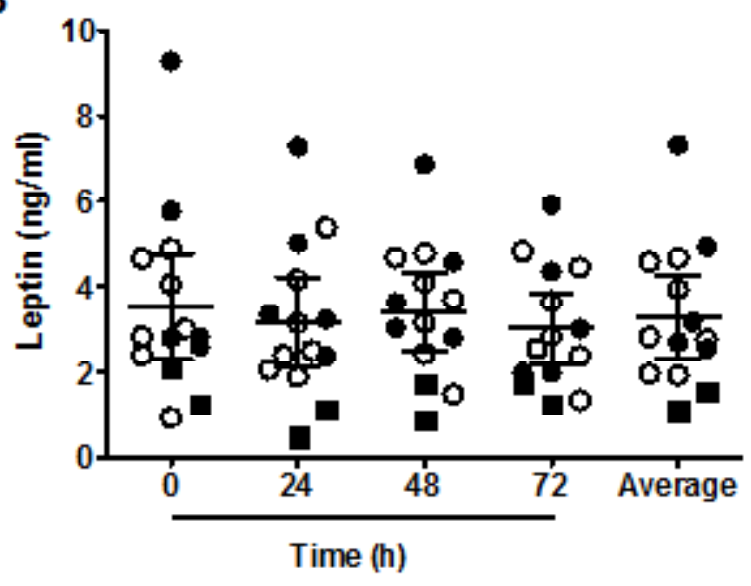

Mean and confidence interval (95\%) for all heifers is depicted in each treatment. Black squares represent two heifers that had an LH preovulatory wave in response to Kiss-10.

There was no significant effect $(P>0.05)$ of treatment, sampling time or treatment by sampling time interaction. 
folicular, así como el diámetro máximo de los folículos dominantes fue similar entre grupos experimentales ( $P>0.05$; Figura 2 ). En este intervalo, la duración de las ondas de desarrollo folicular y el diámetro máximo del folículo dominante aumentaron a partir de la $6^{\mathrm{a}}$ y $5^{\mathrm{a}}$ onda en los grupos testigo y Kisspeptina-10, respectivamente $(\mathrm{P}<0.05)$.

La aplicación repetida de Kiss-10 no modificó $(P>0.05)$ las concentraciones séricas de IGF-1 y leptina, pero las becerras que ovularon en respuesta a Kiss-10 presentaron concentraciones séricas de IGF-1 mayores a las de sus compañeras de grupo $(P<0.05$; Figura $3-A)$, lo cual no ocurrió con las concentraciones séricas de leptina (Figura 3-B), las cuales no variaron durante el período de muestreo; por el contrario, las dos becerras que ovularon fueron de las que presentaron concentraciones de leptina más bajas $(\mathrm{P}<0.05)$.

Las concentraciones séricas de IGF-1 al inicio del periodo experimental se correlacionaron positivamente $(\mathrm{P}<0.05)$ con el peso corporal $(r=0.70)$, la condición corporal $(r=0.58)$ y la altura a la cruz de las becerras $(r=0.78)$. Por su parte, las concentraciones circulantes de leptina sólo se correlacionaron con la edad de las becerras $(r=0.62 ; P<0.05)$. Los valores al inicio del periodo experimental de grosor de grasa dorsal, profundidad del músculo L. dorsi y de variables relacionadas con poblaciones de folículos ováricos, no se correlacionaron con los de las concentraciones séricas de IGF-1 o de leptina ( $P>0.05)$; a su vez, las concentraciones séricas de estas hormonas no se correlacionaron entre sí $(P>0.05)$.

\section{DISCUSIÓN}

En becerras pre-púberes, la Kiss-10 administrada en forma repetida provocó incrementos sucesivos de $\mathrm{LH}$, mismos que disminuyeron en amplitud con el tiempo. De acuerdo con lo que se hipotetizó, la Kiss-10 aplicada repetidamente sería capaz de inducir la ovulación, sin embargo, en el presente estudio esto solo ocurrió en las
Repeated application of Kiss-10 induced $\mathrm{LH}$ increments resembling LH spontaneous pulses that precede puberty. Therefore, Kiss-10 is a potential tool for regulating the reproductive axis in prepubertal heifers as it was reported for rats $(9,10)$ and ewes( $(18)$.

In the present study, LH response to Kiss-10 decreased gradually over time and was similar to spontaneous pulses of $\mathrm{LH}$ in the control group by $24 \mathrm{~h}$ after the initiation of treatments. A similar phenomenon was observed by McLeod et al(16) after administering $\mathrm{GnRH}$ to prepuberal heifers in a pattern resembling that used for Kiss-10 in the present work; authors attributed this response to the effects that ovarian steroids exert over the sensitivity of pituitary to $\mathrm{GnRH}$, instead of the progressive desensitization due to repeated administration of the neurohormone as we propose in the case of Kiss-10 repeated application. It is known that Kiss-10 evokes LH secretion indirectly through the induction of $\mathrm{GnRH}$ release(11), thus in both experiments, the present and that of McLeod et al(16) the desensitization effect could be attributed to the reduced action of GnRH in the pituitary; an alternative mechanism might be the desensitization of GnRH neurons to Kiss-10. This is possible because it was reported that $\mathrm{GnRH}$ neurons experienced refractory intervals to kisspeptin in juvenile mice (28); besides, in the same study, the percentage of depolarized $\mathrm{GnRH}$ neurons and duration of the depolarization period in response to Kiss-10 were lower in prepubertal than in adult animals. Another possible mechanism that may cause the gradual decreased in $\mathrm{LH}$ release during intermittent administration of Kiss-10, is the sudden increase in the rate of LH secretion relative to pretreatment values, as it was documented in proestrus ewes, in which estradiol induced a reduction in amplitude but not in frequency of LH pulses(29). Regardless of the arguments above, it was demonstrated that in adult ewes intermittent administration of Kiss-10, applied intravenously induces the release of $\mathrm{GnRH}$ and $\mathrm{LH}^{(7)}$, as it was also observed for $\mathrm{LH}$ in lambs approaching puberty(18,30), goats in $\operatorname{diestrus}(31)$ 
becerras que presentaron elevadas concentraciones circulantes de IGF-1 y bajas concentraciones de leptina durante el período de muestreo. La Kiss10 no indujo el establecimiento de actividad cíclica ovulatoria o estral, ni afectó el desarrollo folicular ovárico después del tratamiento, por lo que puede considerarse que su efecto fue transitorio.

La Kiss-10 administrada en un protocolo de aplicaciones repetidas provocó un aumento en la frecuencia y magnitud de incrementos de $\mathrm{LH}$ de manera similar a lo que ocurre durante la pubertad. Por lo anterior, es factible proponer a este neuropéptido como una herramienta potencial para la manipulación del eje reproductivo en becerras pre-púberes como se ha sugerido en ratas $(9,10)$ y borregas $(18)$.

En el presente estudio, la magnitud del incremento de LH inducido por cada aplicación de Kiss-10 disminuyó gradualmente con el tiempo hasta llegar a equipararse con la magnitud de los incrementos de LH asociados a pulsos endógenos en el grupo testigo. Una disminución similar en la magnitud de incrementos de LH fue encontrada por McLeod et al(16) después de utilizar un esquema de administración de GnRH similar al de Kiss-10 empleado en el presente trabajo en becerras pre-púberes. Los autores citados, observaron que las becerras presentaron periodos alternados de mayor y menor respuesta a la GnRH exógena, atribuyendo este efecto a la modulación de la sensibilidad de la respuesta hipofisiaria a GnRH ejercida por esteroides ováricos y no a una desensibilización progresiva por efecto de la administración repetida de la neurohormona. El estímulo en la secreción de LH asociado con la administración de Kiss-10, representa un efecto indirecto mediado por la GnRH liberada a nivel hipotalámico en respuesta al neuropéptido(11). En este sentido, no se puede descartar como explicación de la disminución en la magnitud de la respuesta de LH ante aplicaciones repetidas de Kiss-10 a una posible desensibilización de las neuronas GnRH-érgicas, ya que se ha demostrado que and male rats during the beginning of puberty(32). The cited results and data from the present study, provide indirect evidence of a differential sensitivity to Kiss-10 at $\mathrm{GnRH}$ neurons level between pre- and peri-pubertal animals, phenomenon that was reported in rodents $(28,33)$ and Rhesus monkeys $(34)$.

Kiss-10 induced a preovulatory surge of LH and development of a functional $\mathrm{CL}$ in $28 \%$ of heifers. A similar result was obtained in 12 to 14 mo old heifers treated with $\mathrm{GnRH}^{(17)}$ given by the same route, frequency, and time than Kiss-10 in the present experiment. In 5 mo old heifer calves, GnRH induced a preovulatory surge of LH in $75 \%$ of animals and $25 \%$ of them developed a short-lived CL(16); therefore, it is proposed that response of hypothalamus to Kiss-10 and pituitary to GnRH varies with age. That is possible because in prepubertal ewes approaching the onset of puberty, Kiss10(18) and $\mathrm{GnRH}(35)$ administered every hour by 1 and $10 \mathrm{~d}$ respectively, induced an $\mathrm{LH}$ surge and luteal function in more than $60 \%$ of the animals. Similarly, $74 \%$ of rats that were approximately $8 \mathrm{~d}$ before the onset of puberty, a Kiss-10 treatment given every $12 \mathrm{~h}$ for $6 \mathrm{~d}$, advanced the vaginal opening (9). These studies provide evidence about the close association between body development and the proportion of females that present a preovulatory surge of $\mathrm{LH}$ and the subsequent functional $\mathrm{CL}$, in response to intermittent Kiss-10 or GnRH treatments.

In a previous study, prepubertal heifers that were 11-mo old had a greater LH response to an intravenous Kiss-10 bolus than heifers that were 4 and 7 mo old(14); the highest $\mathrm{LH}$ response to Kiss-10 in the 11 old animals coincided with higher concentrations of circulating estradiol and IGF-1, and lower leptin concentrations than in the younger heifers(14). In the present study, calves that had an $\mathrm{LH}$ surge and developed of a $\mathrm{CL}$ in response to Kiss-10, had also the highest levels of IGF-1 and the lowest of leptin. Therefore, estradiol and IGF-1 could modulate positively the 
estas neuronas pueden pasar por periodos refractarios al neuropéptido en ratones juveniles y pre-púberes(28), en los que se observó además que el porcentaje de neuronas de GnRH despolarizadas y la duración del periodo de despolarización en respuesta a Kiss-10, fueron menores en animales pre-púberes que en los de mayor edad.

Por otra parte, la disminución de los incrementos de LH inducidos por la administración intermitente de Kiss-10 puede ser consecuencia del incremento en la frecuencia de secreción de LH con respecto a la del periodo pretratamiento, de manera similar a lo que ocurre en el proestro en animales con actividad cíclica ovulatoria, cuyo estradiol disminuye en amplitud pero no en frecuencia de los pulsos de $\mathrm{LH}^{(29)}$. Independientemente de lo anterior, en borregas adultas la administración i.v. de Kiss-10 en forma intermitente induce un incremento de GnRH y LH similar entre aplicaciones(7), como lo ha sido también para LH en corderas cercanas a la pubertad(18,30), cabras en diestro(31) y ratas macho que han cursado por la pubertad(32). Los resultados citados y los del presente estudio, constituyen evidencias indirectas de una diferenciada sensibilidad a Kiss-10 a nivel de las neuronas $\mathrm{GnRH}$ entre animales pre y peripuberales, fenómeno que fue confirmado para algunos roedores $(28,33)$ y monos Rhesus(34).

La Kiss-10 indujo una oleada preovulatoria de $\mathrm{LH}$ y la formación de un CL funcional en $28 \%$ de las becerras. Un resultado similar se observó en becerras de 12 a 14 meses de edad tratadas con $\mathrm{GnRH}(17)$ por la misma vía, frecuencia y duración del tratamiento que en el presente experimento. En becerras de menor edad, un tratamiento de $\mathrm{GnRH}$ similar al señalado indujo una oleada preovulatoria de LH en $75 \%$ de los animales, de los cuales solo el $25 \%$ formó un $\mathrm{CL}$ de corta duración(16). Por tanto, se propone que la respuesta del hipotálamo a Kiss-10 y de la hipófisis a GnRH exógenas varía en función de la edad de los animales. En apoyo a lo mencionado, en borregas pre-púberes en etapas cercanas al inicio de la pubertad, la Kiss-10(18) kisspeptin effects over the gonadal axis activity. It seems that for induction of puberty, relatively high concentrations of endogenous IGF-1 and estradiol are required as somatic maturity signals, while the effects of leptin signaling may be exerted by increased concentrations during earlier stages of life that declined later on. This phenomenon was reported by our group in an earlier work(14), where in 4 and 7 mo old heifer calves, leptin circulating levels were higher than in 11-mo-old animals. Other authors were unable to produce consistent data relative to the association between leptin circulating levels and the onset of puberty in heifers $(36,37)$.

In the study reported here, all heifers presented a pulsatile LH release of similar characteristics in response to intermittent administration of Kiss-10 during the first $30 \mathrm{~h}$ of treatment; therefore the LH surge and subsequent luteal function observed in some heifers treated with Kiss-10 could be explained, at least partially, by the gonadotropin-stimulation of ovarian steroidogenesis in synergy with high blood levels of IGF-1(38), which in turn would act by a positive feedback action on the hypothalamushypophysial axis. The previous statement is supported by the fact that lambs and rats displayed signs of puberty concurrent with increments of estradiol peripheral concentrations in response to repeated administration of Kiss$10(9,10,18)$. Likewise, Kiss-10 administered continuously to adult ewes induced an LH surge only in those animals that had elevated concentrations of estradiol(39).

The results above suggest that in association with the somatic development which could be evidenced by IGF-1, Kiss-10 evokes an ovulatory response through the induction of a greater $\mathrm{GnRH} / \mathrm{LH}$-induced steroidogenic activity. Despite that in the present study circulating estradiol was not quantified, it confirms partially the available information that supports the concept that the IGF1 and estradiol interactions are important during the processes that determines the onset of puberty. Regarding the actions of IGF-1 and estradiol at central level, these 
y la $\mathrm{GnRH}^{(35)}$ administradas cada hora por 1 y 10 días respectivamente, indujeron una oleada de LH y la función lútea en más del $60 \%$ de ellas. De igual manera, en ratas que aproximadamente se encontraban a ocho días del inicio de la pubertad, un tratamiento de Kiss-10 cada $12 \mathrm{~h}$ por seis días adelantó la apertura vaginal en $74 \%$ de ellas(9). Estos estudios ponen en evidencia la estrecha asociación que parece existir entre el grado de desarrollo corporal y la proporción de hembras que manifiestan una oleada preovulatoria de LH y la subsecuente función lútea, en respuesta a un tratamiento intermitente de Kiss-10 o GnRH.

En un estudio previo con becerras de 4, 7 y 11 meses de edad, se informó que las becerras de 11 meses en comparación de las de menor edad, presentaron la mayor respuesta de $\mathrm{LH}$ a un bolo i.v. de Kiss-10, lo cual coincidió con mayores concentraciones de IGF-1 y estradiol y las menores concentraciones de leptina(14). En el presente estudio, las becerras que presentaron una oleada de LH y formación de CL en respuesta a Kiss-10 presentaron un comportamiento similar en cuanto a IGF-1 y leptina; por lo tanto, la IGF-1 y estradiol podrían modular positivamente los efectos de la kisspeptina en la actividad del eje gonadal, ya que, aparentemente, se requieren concentraciones endógenas relativamente elevadas de dichas hormonas como señal indicadora de desarrollo somático, mientras que los efectos señalizadores de la leptina, si es que se ejercen en becerras, pudieron haber ocurrido mediante incrementos en edades más tempranas, como fue documentado por nuestro grupo en un trabajo anterior(14), donde se determinó que las becerras de 4 y 7 meses de edad tuvieron niveles circulantes de leptina mayores que las de 11 meses de edad; mientras que otros autores no encontraron una asociación consistente entre los niveles de leptina y el inicio de la pubertad en vaquillas $(36,37)$.

En el estudio que aquí se informa, todas las becerras presentaron una liberación pulsátil de LH de características similares en respuesta a hormones interact to affect multiple neural maturation processes $(38,40)$, including: synaptic plasticity in the $\mathrm{GnRH}$ neurons(41), expression of kisspeptin in the anteroventral periventricular nucleus(42), as well as secretion of GnRH and $\mathrm{LH}(43,44)$. These processes take place in hypothalamic regions that regulate, at least in rodents, the occurrence of the LH preovulatory surge (42). In heifers under different growth rates, circulating levels of IGF-1 increased during the accelerated growth phase that precedes the onset of puberty (45). In the present work, IGF-1 was positively associated with variables related to body growth, providing support for the idea that IGF-1 is a signal from somatic tissues which participates in the neuroendocrine maturation events that lead toward puberty, including among them the direct or indirect actions involved on kisspeptin secretion and (or) $\mathrm{GnRH} /$ $\mathrm{LH}$ release. Other evidence that gives support to this concept is that IGF-1 administered to prepuber Rhesus monkeys decreases the LH sensitivity to the negative feedback effects of estrogens(46); besides, in the same animal model, estradiol is essential for the $\mathrm{GnRH}$ release evoked by Kiss-10(47). Therefore, IGF-1 and estradiol seem to promote a greater sensitivity of hypothalamus to kisspeptin; once this action is carried out, a change from negative to positive feedback to estradiol in the hypothalamus follows as well as an increase on frequency of LH secretion, then the LH surge and consequently the first ovulation and the onset of puberty.

In prepubertal heifers, circulating leptin increases several weeks prior puberty(48); however, exogenous leptin did not affect $\mathrm{LH}$ or age to puberty $(49,50)$, therefore it was proposed that leptin may be a permissive hormone for subsequent actions of other agents such as IGF-1 or estradiol(49,50). In addition, suppressed levels of circulating leptin by food restriction $(9,10)$ or by application of antibody against leptin in rats(9), Kiss-10 induced a higher $\mathrm{LH}$ rise than control animals who had normal leptin levels; furthermore, Kiss-10 induced puberty in $60 \%$ of underfed rats with low circulanting leptin, whereas none of the control animals with normal 
la administración intermitente de Kiss-10 durante las primeras $30 \mathrm{~h}$ de tratamiento. Por tanto, la oleada de LH y la subsecuente función lútea observada en algunas becerras tratadas con Kiss-10 podrían explicarse, en parte, por un mayor estímulo a la actividad esteroidogénica inducida por las gonadotropinas hipofisiarias, en sinergia con un elevado nivel sanguíneo de IGF-1(38), retroalimentando con ello positivamente al componente hipotálamo-hipófisis. Es pertinente mencionar que las borregas y ratas con signos de pubertad en respuesta a la administración repetida de $\operatorname{Kiss}-10(9,10,18)$, cursaron también por intervalos de aumentos en las concentraciones sanguíneas de estradiol. Así mismo, en otro estudio se puntualizó que la Kiss-10 administrada en forma continua a borregas adultas, indujo una oleada de LH sólo en aquéllas que respondieron al tratamiento con una elevación de estradiol(39). Estos resultados son sugerentes de que en asociación con el desarrollo somático, el cual podría ser evidenciado indirectamente por IGF-1, la Kiss-10 evoca una respuesta ovulatoria a través de la promoción de una mayor actividad esteroidogénica inducida por la actividad GnRH/ LH. En el presente estudio no se cuantificó el estradiol circulante, pero considerando la información existente en la literatura no se puede ignorar la posible interacción entre IGF1 y estradiol en el inicio de la pubertad.

Por otro lado, a nivel del sistema nervioso central, el IGF-1 y el estradiol interactúan en múltiples procesos de maduración neural( 38,40$)$, entre los que destacan: plasticidad sináptica en las neuronas $\mathrm{GnRH}^{(41)}$, expresión de kisspeptina en el núcleo anteroventral periventricular(42) y secreción de $\mathrm{GnRH}$ y $\mathrm{LH}(43,44)$; procesos que tienen lugar en regiones hipotalámicas encargadas de regular la liberación de LH en forma de oleada(42) al menos en roedores, lo cual podría ser un condicionamiento neural en preparación al eventual inicio de la pubertad. En un estudio efectuado en vaquillas productoras de carne con diferente tasa de crecimiento, se puso de manifiesto el incremento de IGF-1 en sangre leptin began puberty(10). The above discussion allows us to propose that leptin might be an essential element that should increase to threshold levels before puberty, pre-sensitizing the hypothalamus for a subsequent IGF-1 positive action. Once leptin declines, IGF-1 augments and remains elevated in blood for several weeks; then the hypothalamus responds with an enhanced pulsatile release of kisspeptin and GnRH who determine the accelerated rhythm of gonadotropins secretion, which subsequently induces the increased ovarian follicular activity and the rise in circulating estradiol. Increased estrogens evoke the $\mathrm{LH}$ surge and thus the first ovulation occurs during the onset of puberty.

In this study, influences of Kiss-10 treatment were transitory and without further effects beyond those described in the preceding paragraphs. After removal of treatment, LH secretion and follicular development returned to values similar to those in the control group; besides in both groups, post-treatment follicular development followed a pattern resembling the reported in growing heifers, namely the diameter of the dominant follicle and number of follicles increased with age $(51,52)$.

\section{CONCLUSIONS AND IMPLICATIONS}

It is concluded that Kiss-10 applied repeatedly to prepubertal heifers evokes a consistent release of LH and induces ovulation and luteal activity in animals with high IGF-1 but low leptin circulating concentrations; however, Kiss-10 did not induce estrous cyclicity. An implication is that factors that were not evaluated in this work could be present or absent in prepubertal heifers, modulating the kisspeptin effects that would lead to the ovulatory response and the subsequent cyclic activity.

\section{ACKNOWLEDGMENTS}

This work is part of the first author doctoral dissertation. Authors wish to express their 
durante el desarrollo somático precedente al inicio de la pubertad(45). En el presente trabajo, el IGF-1 se asoció positivamente con variables relacionadas con el crecimiento corporal, proporcionando apoyo al concepto de que el IGF-1 es la señal de origen somático que inicia eventos de maduración neuroendocrina conducentes a la pubertad, incluyendo acciones directas o indirectas en la regulación de la secreción de la kisspeptina hipotalámica o los efectos de la Kiss-10 en la secreción de GnRH/ LH. Otras evidencias a favor de dicho concepto se refieren a que el IGF-1 administrado a monas Rhesus durante la adolescencia, disminuye la sensibilidad de la LH a la retroalimentación negativa de los estrógenos(46). Por otro lado, también en monas Rhesus en fase puberal se demostró que el estradiol es indispensable para evocar un aumento de GnRH en respuesta a Kiss-10(47). Por tanto, el IGF-1 y estradiol parecen promover a nivel central una mayor sensibilidad del hipotálamo a la kisspeptina, con lo cual se podría inducir un cambio de retroalimentación negativo a positivo del estradiol en la secreción de LH, y consecuentemente la ovulación.

Con relación a leptina, se ha reportado en vaquillas que los niveles de ésta aumentan en las semanas próximas a la pubertad(48), sin embargo, se ha determinado que sus efectos son permisivos mas no inductivos para el inicio de la misma, pues la leptina exógena no fue suficiente estímulo para aumentar la $\mathrm{LH}$ y adelantar la pubertad en vaquillas $(49,50)$. Además, en ratas con niveles suprimidos de leptina mediante restricción alimenticia $(9,10)$ o mediante la aplicación de anticuerpo contra leptina(9), la Kiss-10 indujo un mayor incremento de LH comparado con los testigos que mostraron niveles normales de leptina. Por otro lado, la supresión de leptina por restricciones de la dieta, indujo la pubertad en $60 \%$ de las ratas tratadas con Kiss-10 en comparación de las ratas con niveles normales de leptina $(0 \%)(10)$. Lo anterior, nos permite proponer que antes del inicio de la pubertad la leptina alcanza una concentración umbral que posteriormente declina antes de la primera ovulación; en appreciation to UNAM, CONACyT and INIFAP for the economic support provided to the first author. Authors also express their gratitude to Dr. Clara Murcia Mejía, who quantified all hormones studied here.

End of english version

seguida el IGF-1 aumenta en sangre y se mantiene elevado, señalizando positivamente al hipotálamo, quien responde con un aumento en la frecuencia pulsátil de kisspeptina y de GnRH, ocasionando aumentos sincrónicos de las gonadotropinas hipofisiarias, lo que a su vez evocaría el aumento de actividad folicular, un incremento del estradiol circulante, la presentación de la oleada preovulatoria de $\mathrm{LH}$ y con ello el desencadenamiento de la pubertad.

En términos prácticos, el tratamiento de Kiss10 fue transitorio y sin repercusión posterior, ya que luego de retirar el tratamiento tanto la secreción de LH como el desarrollo de las ondas foliculares fueron similares a los del grupo testigo. En ambos grupos experimentales, el desarrollo folicular postratamiento siguió un comportamiento característico de las vaquillas en crecimiento, es decir hubo un aumento asociado con la edad(51,52).

\section{CONCLUSIONES E IMPLICACIONES}

Se concluye que la Kiss-10 administrada repetidamente a becerras pre-púberes es un estímulo suficiente para evocar incrementos consistentes de $\mathrm{LH}$, para inducir la ovulación y actividad lútea en animales con concentraciones séricas elevadas de IGF-1 y bajas de leptina, pero no para inducir la ciclicidad estral. Una implicación es que factores diferentes a los aquí evaluados, que están presentes o ausentes en la becerra pre-púber, determinan los efectos de la kisspeptina en la respuesta ovulatoria y subsecuente actividad ovárica cíclica. 


\section{AGRADECIMIENTOS}

Esta información es parte del proyecto de investigación del programa de estudios de Doctorado del primer autor (FMVZ-UNAM). Se agradece a la UNAM, CONACyT e INIFAP por los apoyos económicos proporcionados al primer autor para el desarrollo de sus actividades académicas y de investigación. Se agradece a la MVZ Clara Murcia Mejía, por la cuantificación de hormonas.

\section{LITERATURA CITADA}

1. Patterson DJ, Perry RC, Kiracofe GH, Bellows RA, Staigmiller RB, Corah LR. Management considerations in heifer development and puberty. J Anim Sci 1992;70:4018-4035.

2. Williams GL, Amstalden M. Understanding postpartum anestrus and puberty in the beef. Proc Appl Reprod Strategies in Beef Cattle 2010. San Antonio, TX. [on line] http://www.appliedreprostrategies.com/2010/J anuary/pdfs/ Gary_Williams.pdf. Accesed May, 2013.

3. Ebling JP. The neuroendocrine timing of puberty. Reproduction 2005;129(6):675-683.

4. Moenter SM, DeFazio AR, Pitts GR, Nunemaker CS. Mechanisms underlying episodic gonadotropin-releasing hormone secretion. Front Neuroendocrinol 2003;24(2):7997.

5. Roa J, Aguilar E, Dieguez C, Pinilla L, Tena-Sempere M. New frontiers in Kisspeptin/GPR54 physiology as fundamental gatekeepers of reproductive function. Front Neuroendocrinol 2008; 29:48-69.

6. Oakley $A E$, Clifton $D K$, Steiner RA. Kisspeptin signaling in the brain. Endocr Rev 2009; 30:713-743.

7. Caraty A, Smith JT, Lomet D, Said SB, Morrissey A, Cognie $J$, et al. Kisspeptin synchronizes preovulatory surges in cyclical ewes and causes ovulation in seasonally acyclic ewes. Endocrinology 2007; 148:5258-5267.

8. Messager S, Chatzidaki EE, Ma D, Hendrick AG, Zahn D, Dixon J, Thresher RR, et al. Kisspeptin directly stimulates gonadotropin-releasing hormone release via $\mathrm{G}$ proteincoupled receptor 54. PNAS 2005; 102:1761-1766.

9. Navarro VM, Fernández-Fernández R, Castellano J M, Roa J, Mayen A, Barreiro ML, et al. Advanced vaginal opening and precocious activation of the reproductive axis by KiSS-1 peptide, the endogenous ligand of GPR54. J Physiol 2004; 561:379-386.

10. Castellano J, Navarro V, Fernandez-Fernandez R, Nogueiras R, Tovar S, Roa J, et al. Changes in hypothalamic KiSS-1 system and restoration of pubertal activation of the reproductive axis by kisspeptin in undernutrition. Endocrinology 2005; 146:3917-3925

11. Arreguin-Arevalo JA, Lents CA, Farmieri TA, Nett TM, Clay CM. KiSS-1 peptide induces release of $\mathrm{LH}$ by a direct effect on the hypothalamus of ovariectomized ewes. Anim Reprod Sci 2007;10:265-275.
12. Kadokawa H, Matsui M, Hayashi K, Matsunaga N Kawashima C, Shimizu T, et al. Peripheral administration of kisspeptin-10 increases plasma concentrations of $\mathrm{GH}$ as well as LH in prepubertal Holstein heifers. J Endocrinol 2008; 196: 331-334.

13. Ezzat-Ahmed A, Saito H, Sawada T, Yaegashi T, Yamashita T, Hirata T-I, et al. Characteristics of the stimulatory effect of kisspeptin-10 on the secretion of luteinizing hormone, follicle-stimulating hormone and growth hormone in prepubertal male and female cattle. J Reprod Dev 2009; 55:650-654.

14. Alamilla RM. Respuesta de LH, FSH y GH a una aplicación de kisspeptina en becerras prepúberes de diferentes edades y su asociación con las concentraciones circulantes de leptina, IGF-1 y estradiol [tesis maestría]. México, DF: Universidad Nacional Autónoma de México; 2013.

15. Santos ER, Calderón RRC, Rosete FVJ, Arreguín AJA, Vera AHR, Gutiérrez ACG, et al. Efecto de dos dosis de kisspeptina-10 (Kiss-10) en la liberación de LH y FSH y su asociación con la composición corporal y leptina sérica en becerras prepúberes [resumen]. Reunión Nacional de Investigación Pecuaria. 2011:113.

16. McLeod BJ, Peters AR, Haresign W, Lamming GE. Plasma $\mathrm{LH}$ and $\mathrm{FSH}$ responses and ovarian activity in prepubertal heifers treated with repeated injections of low doses of GnRH for 72 h. J Reprod Fert 1985: 74:589-595.

17. Skaggs $\mathrm{CL}$, Able BV, Stevenson JS. Pulsatile or continuous infusion of luteinizing hormone-releasing hormone and hormonal concentrations in prepubertal beef heifers. J Anim Sci 1986;62:1034-1048.

18. Redmond RS, Macedo GG, Velez IC, Caraty A, Williams GL, Amstalden M. Kisspeptin activates the hypothalamicadenohypophyseal- gonadal axis in prepubertal ewe lambs. Reproduction 2011; 141:541-548.

19. García E. Modificaciones al Sistema de Clasificación climática de Koopen. 4th ed., Instituto de Geografía, UNAM, México, 194; 1988.

20. Wildman EE, J ones GM, Wagner PE, Bowman RL, Troutt HF, Lesch TN. A dairy cow body condition scoring system and its relationship to selected production characteristics. JDS 1982; 65:495-501.

21. Williams AR. Ultrasound applications in beef cattle carcass research \& management. J Anim Sci 2002;80(Suppl 2):183188.

22. Calderón RRC, Villa-Godoy A, Lagunes LJ, Fajersson P. Desarrollo folicular en vaquillas cebú y suizo pardo peripúberes en condiciones tropicales. Téc Pecu Méx 2000; 38: 163-175.

23. Arrieta E, Porras A, González-Padilla E, Murcia C, Rojas S, Perera-Marín G. Ovine serum and pituitary isoforms of luteinising hormone during the luteal phase. Reprod Fert Dev 2006; 18:485-495.

24. Perera-Marín G, Murcia C, Rojas S, Hernández-Cerón J, González-Padilla E. Pattern of circulating luteinizing hormone isoforms during the estrous and luteal phases in Holstein heifers. Anim Reprod Sci 2005; 86:53-69.

25. Delavaud C, Ferlay A, Faulconnier Y, Bocquier F, Kann G, Chilliard Y. Plasma leptin concentration in adult cattle: effects of breed, adiposity, feeding level, and meal intake. J Anim Sci 2002; 80:1317-1328.

26. Pierson RA, Ginther JO. Ultrasonography of the bovine ovary. Theriogenology 1984;21(3):495-504. 
27. SAS. Statistical Analysis System Institute Inc, Cary, NC, USA. 2002.

28. Han SK, Gottsch ML, Lee KJ, Popa SM, Smith JT, Jakawich SK, et al. Activation of gonadotropin-releasing hormone neurons by kisspeptin as a neuroendocrine switch for the onset of puberty. J Neurosci 2005;25:11349-11356.

29. Goodman RL, Karsch FJ. Pulsatile secretion of luteinizing hormone: differential suppression by ovarian steroids. Endocrinology 1980;107:1286-1290.

30. Wang J, Sun L, Zhang T, Zhou H, Lou Y. Effect of peripheral administration of kisspeptin-10 on dynamic LH secretion in prepubertal ewes. AJAS 2012; 25; 785-788.

31. Hashizume $T$, Saito $H$, Sawada $T$, Yaegashi $T$, Ezzat AA, Sawai K, et al. Characteristics of stimulation of gonadotropin secretion by kisspeptin-10 in female goats. Anim Reprod Sci 2010:118:37-41.

32. Tovar S, Vázquez MJ, Navarro VM, Fernández-Fernández R, Castellano J M, Vigo E et al. Effects of single or repeated intravenous administration of kisspeptin upon dynamic LH secretion in conscious male rats. Endocrinology 2006; 147:2696-2704.

33. Navarro VM, Castellano J M, Fernández-Fernández R, Barreiro ML, Roa J, Sanchez-Criado JE, et al. Developmental and hormonally regulated messenger ribonucleic acid expression of KiSS-1 and its putative receptor, GPR54, in rat hypothalamus and potent luteinizing hormone-releasing activity of KiSS-1 peptide. Endocrinology 2004;145:45654574.

34. Shahab M, Mastronardi C, Seminara SB, Crowley WF, Ojeda SR, Plan TM. Increased hypothalamic GPR54 signaling: a potential mechanism for initiation of puberty in primates. PNAS 2005; 102:2129-2134.

35. Pirl KG, Adams TE. Induction of precocious puberty in ewe lambs by pulsatile administration of $\mathrm{GnRH}$. J Reprod Fert 1987; 80:355-359.

36. Zulu VCh, Nakao T, Sawamuka Y. Insulin-growth like factor I as a possible hormonal mediator nutritional regulation of reproduction in cattle. J Vet Med Sci 2002;64(8):657-665.

37. Block SS, Smith J M, Ehrhardt RA, Diaz MC, Rhoads RP, Van Amburgh ME Boisclair YR. Nutritional and developmental regulation of plasm leptin in dairy cattle. J Dairy Sci 2003; 86: 3206-3214.

38. Chelikani PK, Ambrose DJ, Keisler DH, Kennelly JJ. Effects of dietary energy and protein density on plasma concentration of leptin and metabolic hormones in dairy heifers. J Dairy Sci 2009;92:1430-1441.

39. Sébert $M E$, Lomet $D$, Ben Saïd $S$, Monget $P$, Briant $C$, Scaramuzzi RJ, et al. Insights into the mechanism by which kisspeptin stimulates a preovulatory LH surge and ovulation in seasonally acyclic ewes: Potential role of estradiol. Dom Anim Endo 2010; 38:289-298.
40. Mendez, P, Azcoitia I, Garcia-Segura LM. Interdependence of oestrogen and insulin-like growth factor-I in the brain: potential for analysing neuroprotective mechanisms. J Endocrinol 2005; 185:11-17.

41. DiVall SA, Williams TR, Carver SE, Koch L, Brüning J C, Kahn $\mathrm{R}$, et al. Divergent roles of growth factors in the $\mathrm{GnRH}$ regulation of puberty in mice. JCl 2010;120:2900-2909.

42. Hiney JK, Srivastava VK, Pine MD, Dees WL. Insulin-like growth factor-I activates KiSS-1 gene expression in the brain of the prepubertal female rat. Endocrinology 2009; 150: 376-384.

43. Hiney JK, Srivastava V, Nyberg CL, Ojeda SR, Dees WL. Insulin-like growth factor-I of peripheral origin acts centrally to accelerate the initiation of female puberty. Endocrinology 1996; 137: 3717-3727.

44. Hiney JK, Srivastava V, Dearth RK, Dees WL. Influence of estradiol on insulin-like growth factor-1-induced luteinizing hormone secretion. Bra Res 2004:1013:91-97.

45. Yelich J V, Wettemann RP, Marston TT, Spicer LJ. Luteinizing hormone, growth hormone, insulin-like growth factor-I, insulin and metabolites before puberty in heifers fed to gain at two rates. Dom Anim Endocrinol 1996; 13:325-338.

46. Wilson ME. IGF-I administration advances the decrease in hypersensitivity to oestradiol negative feedback inhibition of serum LH in adolescent female rhesus monkeys. J Endocrinol 1995; 145(1): 121-130.

47. Guerriero KA, Keen KL, Millar RP, Terasawa E. Developmental changes in $\mathrm{GnRH}$ release in response to kisspeptin agonist and antagonist in female rhesus monkeys (Macaca mulatta): implication to the mechanism of puberty. Endocrinology 2012; 153: 825-836.

48. Garcia MR, Amstalden M, Williams SW, Stanko RL, Morrison CD, Keisler DH, Nizielski SE, Williams GL. Serum leptin and its adipose gene expression during pubertal development, the estrous cycle, and different seasons in cattle. J Anim Sci 2002; 80:2158-2167.

49. Maciel MN, Zieba DA, Amstalden M, Keisler DH, Neves JP, Williams GL. Chronic administration of recombinant ovine leptin in growing beef heifers: Effects on secretion of $\mathrm{LH}$, metabolic hormones, and timing of puberty. J Anim Sci 2004; 82: 2930-2936.

50. Zieba DA, Amstalden M, Morton S, Maciel MN, Keisler DH, Williams GL. Regulatory roles of leptin at the hypothalamichypophyseal axis before and after sexual maturation in cattle. BOR 2004; 71:804-812.

51. Rawlings NC, Evans ACO, Honaramooz A, Bartlewski PM. Antral follicle growth and endocrine changes in prepubertal cattle, sheep and goats. Anim Reprod Sci 2003;78:259270.

52. Nogueira GP. Puberty in south american bos indicus (Zebu) cattle. Anim Reprod Sci 2004;82-83:361-372. 